\title{
SLIT1 wt Allele
}

National Cancer Institute

\section{Source}

National Cancer Institute. SLIT1 wt Allele. NCI Thesaurus. Code C126783.

Human SLIT 1 wild-type allele is located within 10q23.3-q24 and is approximately $188 \mathrm{~kb}$ in length. This allele, which encodes slit homolog 1 protein, is involved in both angiogenesis and axon guidance. 